\title{
Eruption and emplacement timescales of ignimbrite super-eruptions from thermo-kinetics of glass shards
}

\section{Yan Lavallée ${ }^{1 *}$, Fabian B. Wadsworth ${ }^{1,2}$, Jérémie Vasseur ${ }^{2}$, James K. Russell ${ }^{3}$, Graham D. M. Andrews ${ }^{4}$, Kai-Uwe Hess ${ }^{2}$, Felix W. von Aulock ${ }^{1}$, Jackie E. Kendrick ${ }^{1}$, Hugh Tuffen ${ }^{5}$, Andrew J. Biggin ${ }^{1}$ and Donald B. Dingwell ${ }^{2}$}

${ }^{1}$ Earth, Ocean and Ecological Sciences, University of Liverpool, Liverpool, UK

2 Earth and Environment, Ludwig Maximilan University of Munich, Munich, Germany

${ }^{3}$ Volcanology and Petrology Laboratory, Earth, Ocean and Atmospheric Sciences, University of British Columbia, Vancouver, BC, Canada

${ }^{4}$ Department of Geology, California State University Bakersfield, Bakersfield, CA, USA

${ }^{5}$ Lancaster Environment Centre, Lancaster University, Lancaster, UK

Edited by:

Luis E. Lara, Servicio Nacional de

Geología y Minería, Chile

Reviewed by:

Luca Caricchi, University of Geneva, Switzerland

Roberto Sulpizio, Università degli

Studi di Bari, Italy

\section{*Correspondence:}

Yan Lavallée, Experimental

Volcanology Laboratory, Earth,

Ocean and Ecological Sciences,

Jane Herdman Building, 4 Brownlow

Street, Liverpool, L69 3GP, UK

e-mail:yan.lavallee@liverpool.ac.uk
Super-eruptions generating hundreds of cubic kilometers of pyroclastic density currents are commonly recorded by thick, welded and lava-like ignimbrites. Despite the huge environmental impact inferred for this type of eruption, little is yet known about the timescales of deposition and post-depositional flow. Without these timescales, the critical question of the duration of any environmental impact, and the ensuing gravity of its effects for the Earth system, eludes us. The eruption and welding of ignimbrites requires three transects of the glass transition. Magma needs to: (1) fragment during ascent, (2) liquefy and relax during deposition, agglutination and welding (sintering), and (3) quench by cooling into the glassy state. Here we show that welding is a rapid, syn-depositional process and that the welded ignimbrite sheet may flow for up to a few hours before passing through the glass transition a final time. Geospeedometry reveals that the basal vitrophyre of the Grey's Landing ignimbrite underwent the glass transition at a rate of $\sim 0.1^{\circ} \mathrm{C}$. $\mathrm{min}^{-1}$ at $870^{\circ} \mathrm{C}$; that is, $30-180^{\circ} \mathrm{C}$ below pre-eruptive geothermometric estimates. Application of a 1-D cooling model constrains the timescale of deposition, agglutination, and welding of the basal vitrophyre to less than $1 \mathrm{~h}$, and possibly even tens of minutes. Thermo-mechanical iteration of the sintering process indicates an optimal temperature solution for the emplacement of the vitrophyres at $966^{\circ} \mathrm{C}$. The vitrophyres reveal a Newtonian rheology up to $46 \mathrm{MPa}$, which suggests that the ash particles annealed entirely during welding and that viscous energy dissipation is unlikely from loading conditions alone, unless shear stresses imposed by the overlying ash flow were excessively high and sustained over long distances. The findings underline the value of the term "lava-like" flow to describe the end rheology of Snake River-type ignimbrites, fully consistent with the typical lithofacies observed.

Keywords: ignimbrite volcanism, snake river plain, geospeedometry, glass transition, liquid relaxation, eruption timescale

\section{INTRODUCTION}

Large explosive (super-) eruptions of silicic magma commonly generate extensive pyroclastic density currents, preserved in the geologic record as ignimbrites, classically termed pumice-andash-flow tuff (Sparks, 1976; Sparks et al., 1978; Walker et al., 1981; Wilson and Walker, 1982; Walker, 1983; Wilson, 1985; Fisher et al., 1993; Freundt and Schmincke, 1995; Kobberger and Schmincke, 1999). During deposition from the pyroclastic density currents, agglutination, sintering, and welding of liquid globules of ash and pumice lapilli likely change the flow behavior from particulate to coherent and non-particulate (Branney and Kokelaar, 1992; Gottsmann and Dingwell, 2001a). Architectural descriptions of high-grade ignimbrites often provide evidence for both syn- and post-depositional development of rheomorphic, ductile shear zones and "lava-like" lithofacies (Schmincke and
Swanson, 1967; Chapin and Lowell, 1979; Branney and Kokelaar, 1992; Moore and Kokelaar, 1998; Kokelaar and Koniger, 2000; Sumner and Branney, 2002; Andrews and Branney, 2011; Brown and Bell, 2013). Welding textures have been reported from a range of physical environments: in conduits (Tuffen et al., 2003; Tuffen and Dingwell, 2005; Noguchi et al., 2008; Kolzenburg et al., 2012; Lavallée et al., 2012), at the base of lava flows (Manley, 1992, 1995, 1996), in impact crater ejecta blankets (Dence, 1971; Kraut and French, 1971) and in ignimbrites, both proximal (Mellors and Sparks, 1991) and distal (Quane and Russell, 2005a; Andrews et al., 2008; Branney et al., 2008; Brown et al., 2008; Trofimovs et al., 2008; Ellis et al., 2011). For the case of ignimbrites, two end-member stages of rheomorphism are postulated: syn-depositional/syn-welding flow (e.g., Branney and Kokelaar, 1992; Andrews and Branney, 2011) and late-stage 
post-depositional compaction; welding and viscous flow (e.g., Schmincke and Swanson, 1967; Kobberger and Schmincke, 1999). Microstructural studies of the deformation history outlining the complex depositional dynamics of such rheomorphism have led to the former scenario being favored (Andrews et al., 2008; Andrews and Branney, 2011). The physico-chemical character of the deposits, especially where developing into shear zones, has direct rheological consequences for flow, where viscous energy dissipation may cause heating by tens if not hundreds of degrees (Robert et al., 2013). Recent work on ignimbrites has provided greatly improved, detailed, process-oriented descriptions of deposit formation (Andrews and Branney, 2011), but the timescales of deposition and post-depositional flow remain largely unconstrained. Here we take advantage of the fact that vitrophyres - that is, the original glassy material formed on initial quenching of the deposits - may hold invaluable kinetic constraints on the emplacement dynamics.

Rheologically (or kinetically) the eruption and welding of ignimbrites requires three crossings of the glass transition $\left(T_{g}\right)$ (Gottsmann and Dingwell, 2001a). Magma needs to: (1) fragment to ash during ascent and eruptive fountaining, (2) liquefy and relax during transport, deposition, agglutination and welding at high temperature, and lastly (3) quench by cooling into the glassy state. The structure of the glass frozen in at $T_{g}$ reflects kinetic information from the point at which structural relaxation ceases (Dingwell and Webb, 1990). The cooling path dependence of $T_{g}$ and its role in forming glass thus holds information as to the cooling rate of magma, which is experimentally accessible via geospeedometric approaches (Gottsmann and Dingwell, 2001a; Gottsmann et al., 2004). Here, we combine rheological measurements, chemical analysis, glass geospeedometry and a 1D analytical thermo-mechanical model to assess the physicochemical evolution and, specifically, to constrain the duration of eruption, deposition and cooling of a high-grade ignimbrite in the Snake River Plain (USA).

\section{GREY'S LANDING IGNIMBRITE}

The Late Miocene Grey's Landing member is a high-grade ignimbrite resulting from Snake-River (SR)-type volcanism (Branney et al., 2008), preserved in the Rogerson Graben and inferred to originate several tens of kilometers to the east, on the southern margin of the Twin Falls eruptive center (Figure 1; Cathey and Nash, 2004; Andrews and Branney, 2011). Detailed studies of the ignimbrite have described a 5-75-m thick deposit unit divided into a (1) basal vitrophyre, overlain by (2) a thick, parataxitic, lithoidal core, (3) a thin upper vitrophyre, and sometimes (4) a non-welded top (Andrews et al., 2008; Andrews and Branney, 2011). The vitrophyres are generally continuous and do not exhibit evidence of any large-scale folding or brittle failure resulting from vigorous post-depositional flow (c.f., Branney et al., 2004). The basal and upper vitrophyres consist of a poorly sorted mixture of densely-welded ( $\sim 0.075$ and 0.095 pore volume fraction, respectively) glass shards with mildly eutaxitic fabrics and containing small amounts $(<5 \%)$ of microlites of andesine, pigeonite, augite, hypersthene, and titanomagnetite (Figure 2). Previous geothermobarometry study on pigeonite-augite crystal pairs suggests pre-eruptive magmatic temperatures ranging between 900 and $1050^{\circ} \mathrm{C}$ (Andrews et al., 2008)—a temperature range constrained by setting pressure to $5 \mathrm{kbar}$ (Cathey and Nash, 2004), based on on isotopic analysis for these high-temperature, low $\mathrm{d}^{18} \mathrm{O}$ rhyolite work (Leeman et al., 2008).

\section{GEOCHEMICAL ANALYSIS}

On the basis of bulk whole-rock analysis, the Grey's Landing ignimbrite comprises an anhydrous, metaluminous rhyolite with $72.5 \mathrm{wt} \% \mathrm{SiO}_{2}$ (Table 1; Andrews et al., 2008). The chemical composition of the interstitial glass and, importantly, its volatile content provide some first order constraints on its melt rheology. The glass, as measured by electron probe micro-analysis, is also a metaluminous rhyolite and here we constrain its rheology using the model for hydrous, metaluminous melts (Hess and Dingwell, 1996).

We quantified the volatile content of the glass using a simultaneous differential scanning calorimeter/thermal gravimetric analyser (DSC-TGA) with exsolved gas analysis (mass spectrometer, MS). Standard procedures for DSC-TGA analysis were followed (Newman et al., 1986; Denton et al., 2009) with two heating cycles to $1250^{\circ} \mathrm{C}$ at $5^{\circ} \mathrm{C} \cdot \mathrm{min}^{-1}$.

During the first heating cycle the sample lost $2.61 \mathrm{wt} \%$, indicative of its total volatile content (Figure 3). Insignificant weight loss during the second heating cycle bears testimony to the near-complete nature of the degassing occurring during the first heating cycle. Degassing occurred over a broad temperature range from 200 to $500^{\circ} \mathrm{C}$. The rate of weight loss peaked at $298^{\circ} \mathrm{C}$ and corresponded well with the peak $\mathrm{H}_{2} \mathrm{O}$ count recorded in the MS, indicating that the weight loss was dominated by water, although $\mathrm{CO}_{2}, \mathrm{~F}$, and $\mathrm{Cl}$ loss also occurred (at concentrations carrying minor rheological impacts on silicate liquids, Hess and Dingwell, 1996; Morizet et al., 2007). Using the relative magnitudes of the MS species counts water is estimated to comprise $92 \%$ of the volatiles lost, giving an estimated water content of 2.39 wt.\%. Water loss predominantly occurred at low temperatures, indicating that molecular water concentrations greatly exceeded those of hydroxyl (Denton et al., 2009, 2012). The water speciation is therefore typical of low, significantly sub-magmatic temperatures (e.g., Stolper, 1989). We propose that molecular water entered the sample pore space at temperatures $<500^{\circ} \mathrm{C}$ during post-depositional hydration (Denton et al., 2009), due to the high solubility, yet low diffusivity of water in silicate glass at low temperature (Zhang et al., 2007), and that little disassociated magmatic water was present. An important implication is that a trivial amount of magmatic volatiles were present in the melt as it last crossed the glass transition, suggesting that degassing was near-complete in this explosive super-eruption.

\section{ROCK-MAGNETIC SIGNATURE}

We employed a magnetic measurements variable field translation balance (VFTB) to measure the Isothermal Remanent Magnetisation (IRM), backfield, hysteresis and thermomagnetic curves to help identify the magnetomineralogy and domain state in the basal vitrophyre as well as constrain the conditions at which the sample hydrated (Figure 4). For this purpose, small cylinders of vitrophyre (6 $\mathrm{mm}$ diameter and $5 \mathrm{~mm}$ high) were subjected to varying applied magnetic fields and the resulting 


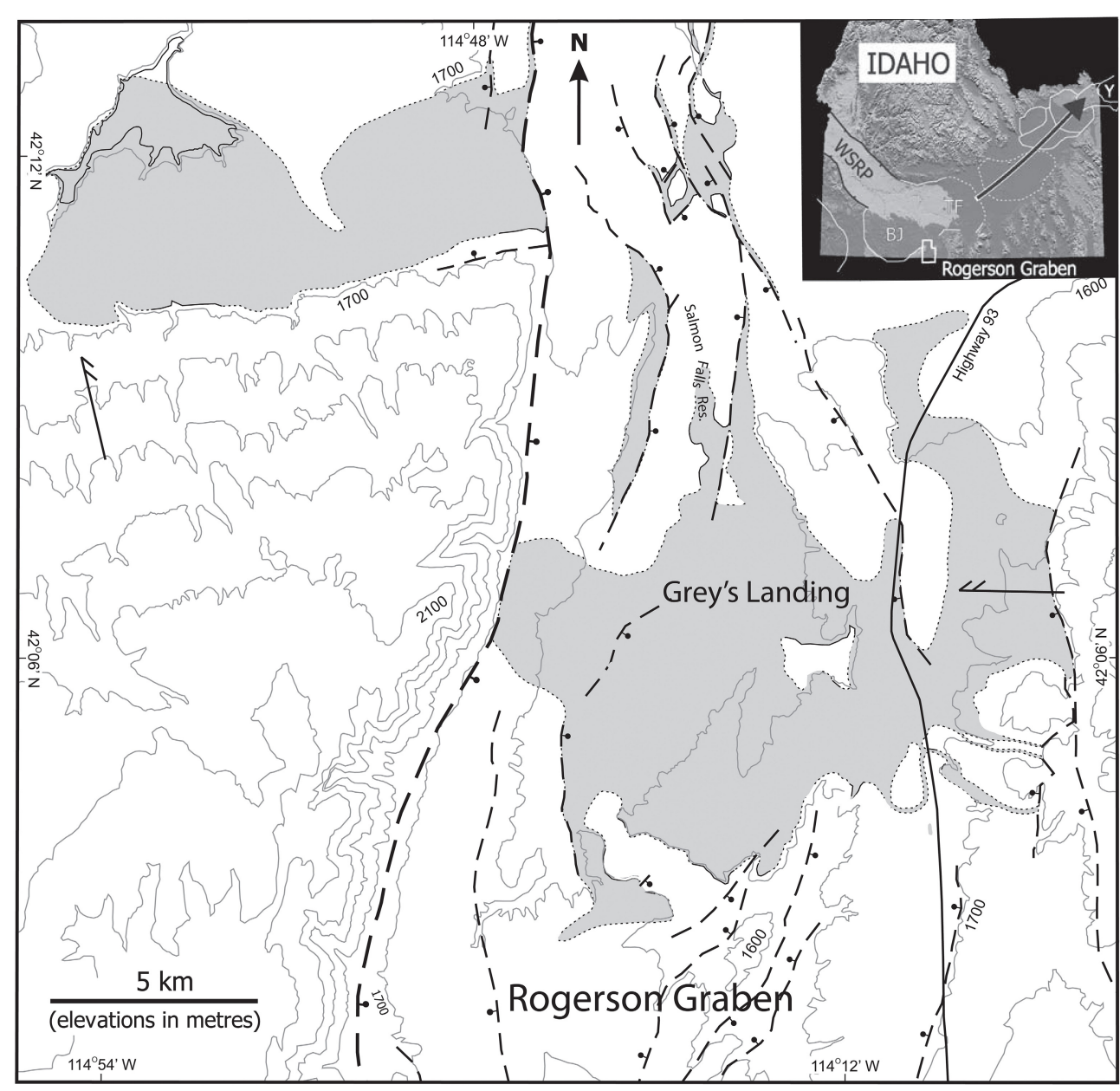

FIGURE 1 | Extent of the Grey's Landing ignimbrite (shaded in gray) in the Rogerson Gragen, Snake River Plain, Idaho, USA.

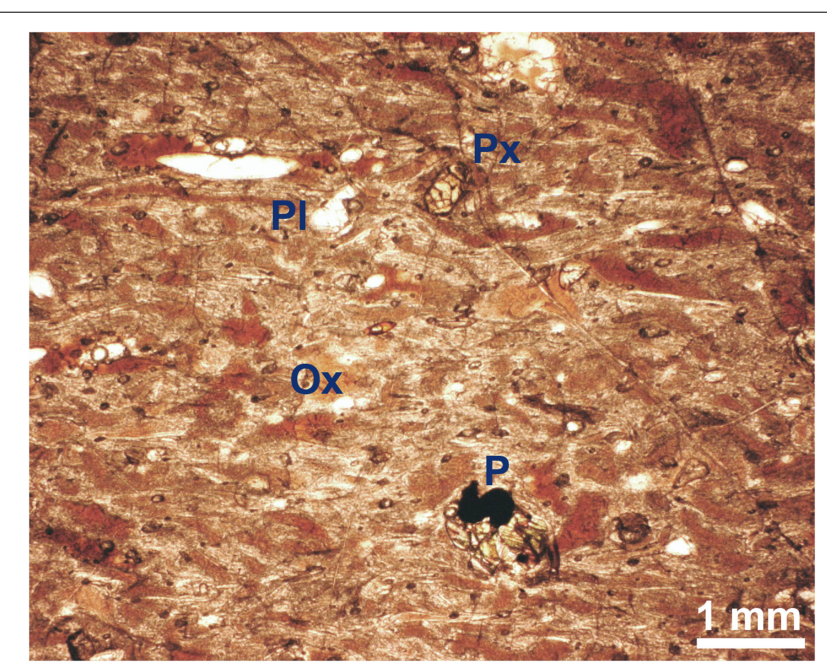

FIGURE 2 | Photomicrogragh of the Grey's Landing basal vitrophyre showing a dense agglomerate of eutaxitic glass shards with moderate aspect ratio (3:5). The glass hosts a small amount of plagioclase (PI), pyroxene $(\mathrm{Px})$, oxide (in white) and pores.
Table 1 | Chemical composition of the Grey's Landing basal vitrophyre.

\begin{tabular}{lccc}
\hline Oxides & Glass $\mathbf{1}$ & Glass 2 & Bulk \\
\hline $\mathrm{SiO}_{2}$ & 79.088 & 78.876 & 72.543 \\
$\mathrm{Al}_{2} \mathrm{O}_{3}$ & 11.965 & 12.050 & 11.812 \\
$\mathrm{Na}_{2} \mathrm{O}$ & 1.862 & 1.754 & 2.995 \\
$\mathrm{~K}_{2} \mathrm{O}$ & 5.897 & 5.934 & 5.174 \\
$\mathrm{MgO}$ & 0.000 & 0.006 & 0.239 \\
$\mathrm{CaO}$ & 0.295 & 0.264 & 1.448 \\
$\mathrm{TiO}_{2}$ & 0.330 & 0.357 & 0.499 \\
$\mathrm{Fe}_{2} \mathrm{O}_{3}$ & 0.442 & 0.497 & 3.501 \\
$\mathrm{MnO}$ & 0.005 & 0.027 & 0.064 \\
$\mathrm{P}_{2} \mathrm{O}_{5}$ & 0.019 & 0.035 & 0.082 \\
$\mathrm{Cl}$ & 0.030 & 0.027 & - \\
$\mathrm{LOI}$ & - & - & 1.911 \\
$\mathrm{Total}$ & 99.932 & 99.826 & 100.267 \\
\hline
\end{tabular}

The interstitial glass was analyzed with a CAMECA SX100 electron microprobe, using a defocused beam [15 KV, $20 \mathrm{nA}$ scanning box mode $(102 \mu \mathrm{m} 2)]$ and the calibration standards: $\mathrm{Na}$, albite; $\mathrm{K}$, orthoclase; 12 , rhyolite. Bulk rock analysis were obtained by XRF (Andrews et al., 2008). 
magnetisation was measured both before (hysteresis) and after (IRM and backfield) switching the field off. Subsequently, the samples were placed in a constant field of $240 \mathrm{mT}$ and heated in air to $700^{\circ} \mathrm{C}$ and then cooled back down to room temperature. The dataset was analyzed using the RockMagAnalyzer software

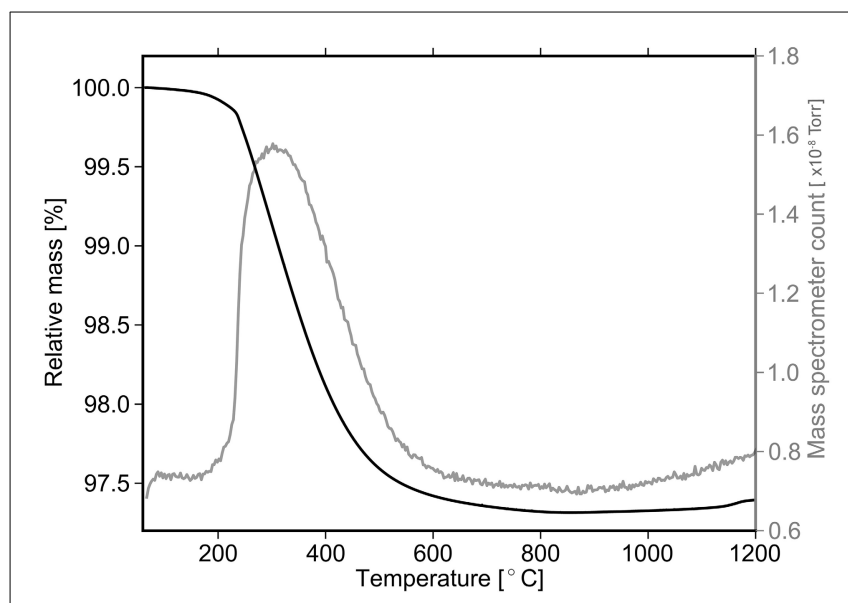

FIGURE 3 | Thermal analysis showing weight loss and mass spectrometer count for $\mathrm{H}_{2} \mathrm{O}$ (AMU 18) associated with heating at a rate of $5^{\circ} \mathbf{C} \cdot \mathrm{min}^{-1}$ from 50 to $1250^{\circ} \mathrm{C}$. The strong correlation shows that degassing is dominated by the loss of molecular water from the sample. by Leonhardt (2006). We find a good consistency between all samples. IRM and backfield curves (Figures 4A,B) show evidence for both low and (minor) high coercivity phases with saturation not fully achieved by $800 \mathrm{mT}$. The hysteresis loop (Figure 4C) also shows some "wasp-waisting" (Tauxe et al., 1996) suggesting that phases with very different coercivity are present within the sample. The bulk hysteresis properties give a remanent magnetization/ saturation magnetization (Mrs/Ms) of 0.19 and the coercivity of remanence/coercive force $(\mathrm{Bcr} / \mathrm{Bc})$ of 5.6 placing it within the pseudo single-domain (PSD) region of the Day et al. (1977) plot close to the single-/multi-domain (SD/MD) mixing line of Dunlop (2002). All thermomagnetic heating and cooling curves (undertaken in air) show at least two Curie Temperatures in the basal vitrophyre (Figure 4D). The first is at $210-230^{\circ} \mathrm{C}$, likely representing an $\mathrm{Fe}-\mathrm{Ti}$ oxide (potentially a near-primary titanohaematite), and the second at $550-580^{\circ} \mathrm{C}$ indicating nearstoichiometric magnetite.

The difference in shape of the cooling and heating curves suggests that during laboratory heating, the Fe-Ti oxide grains were variably oxidized to have more distributed, higher Curie Temperatures and higher saturation magnetisation values. The results suggest that this rock was originally subject to oxidation of its primary magnetic phases at elevated temperatures but that it cooled too quickly to achieve equilibrium. We do not find evidence for (titano) maghaemite which suggests the oxidation was confined to temperatures at least above
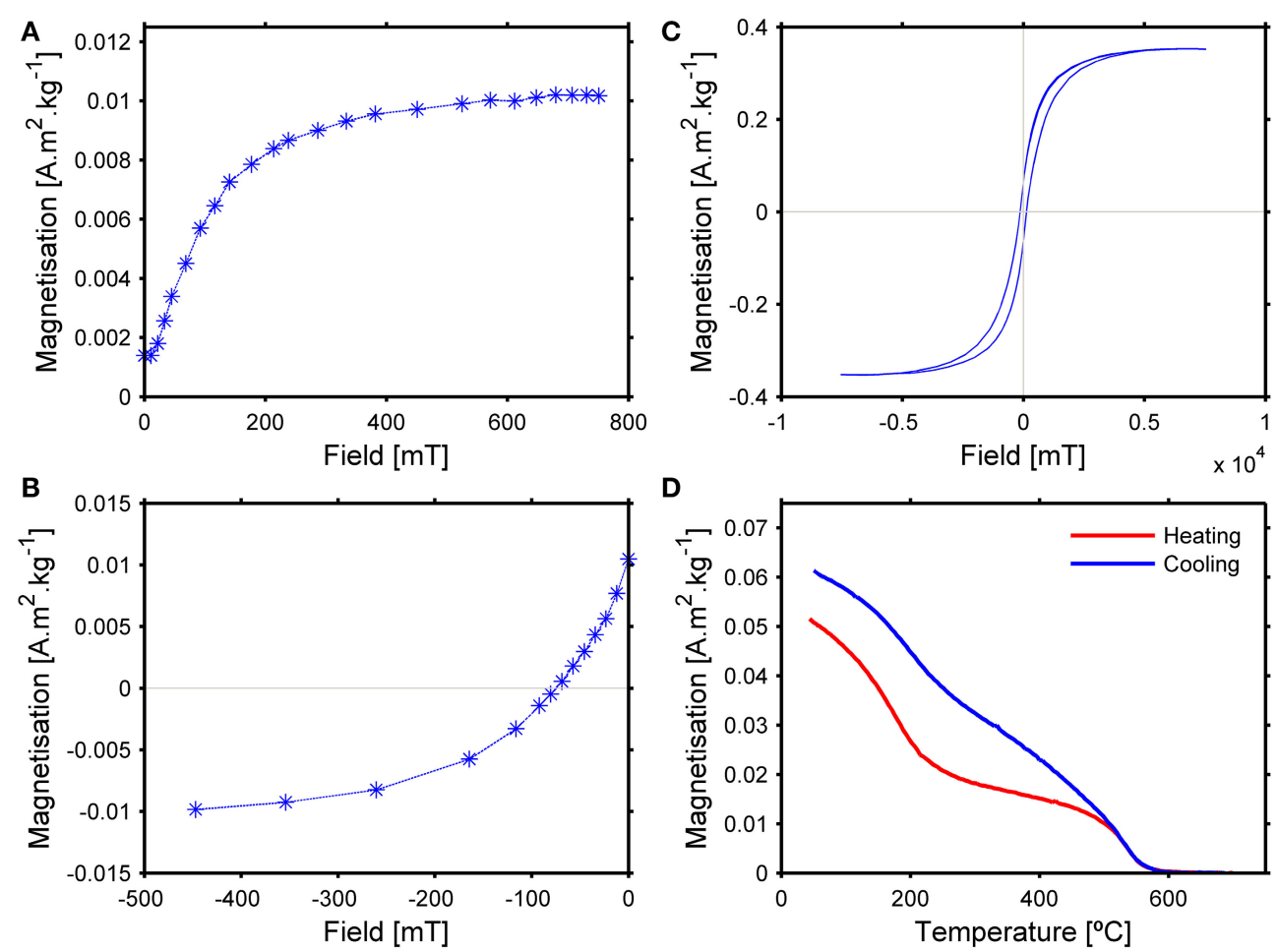

FIGURE 4 | Magnetic properties of the basal vitrophyre, measured in a variable field translation balance (VFTB). (A) IRM curve, and (B) Backfield IRM curve: both showing evidence for both low and (minor) high coercivity phases with saturation not fully achieved by

$800 \mathrm{mT}$; (C) Hysteresis loop, used for estimating a Mrs/Ms of 0.19 and a Bcr/Bc of 5.6; (D) Thermomagnetic Curves (undertaken in air) show at least two Curie Temperatures at $210-230^{\circ} \mathrm{C}$, and at $550-580^{\circ} \mathrm{C}$. 
$200^{\circ} \mathrm{C}$. Similarly, the presence of a Ti-rich phase and its readiness to alter under laboratory heating supports limited (or no) primary oxidation occurring above $700^{\circ} \mathrm{C}$. This iron oxidation temperature constraint is concordant with the observation that sample dehydration reaction around $<500^{\circ} \mathrm{C}$ (Figure 3) may reflect a late, post-magmatic hydration phase by meteoric water.

\section{GEOSPEEDOMETRY}

A differential scanning calorimeter (DSC) was used to quantify the glass transition temperature and to derive the natural cooling rate of the interstitial glass. $55.99 \mathrm{mg}$ of crushed glass were selected, washed with acetone and oven-dried at $110^{\circ} \mathrm{C}$ for $60 \mathrm{~min}$. Specific heat capacities of the glass shards (placed in a lidded platinum crucible) were measured in argon atmosphere in a DSC calibrated against a single crystal sapphire of similar mass in identical measurement conditions. The samples were treated to $950^{\circ} \mathrm{C}$ in successive heating/cooling runs at matching cooling and heating rates of 10/10,10/10,20/20,15/15,10/10, and $5 / 5^{\circ} \mathrm{C}$. $\mathrm{min}^{-1}$ (details of the method and volcanology applicability can be found in Scherer, 1990; Wilding et al., 1995, 1996; Gottsmann and Dingwell, 2001a,b). Geospeedometry requires fitting the raw heat capacity curve of the first heating cycle (from original samples with an unknown, natural cooling rate) by modeling the heat capacity peaks associated with the glass transition of each cooling/heating cycle of a known rate.

During the first heating run, we observe a broad peak in heat capacity at $250-600^{\circ} \mathrm{C}$ and a narrow peak associated with the transition of the glass to a supercooled melt at $800-920^{\circ} \mathrm{C}$, which peaks at $870^{\circ} \mathrm{C}$ (Figure 5A). We attribute the low-temperature DSC peak to devolatilisation of molecular water, as it coincides well with the temperature range of degassing in TGA measurements. In the following runs, the low-temperature peak is absent and only the glass transition peak remains, although the measured heat capacities progressively diminish. Extrapolation of the glass transition peaks can be used to estimate the natural cooling rate of a liquid as it vitrifies. Note that it remains possible that the accuracy of geospeedometric estimates may be jeopardized if post-depositional hydration were to modify the structure originally trapped in at the glass transition; no rheological studies yet account for such a phenomenon. Here, application of geospeedometry provides us with an estimate of the cooling rates of the basal vitrophyre at $\sim 0.1^{\circ} \mathrm{C} \cdot \mathrm{min}^{-1}$ (Figure 5B).

\section{"LAVA-LIKE" RHEOLOGY}

The viscosity of the Grey's Landing melt was investigated through dilatometric measurements. Cylindrical disks with heights and diameters of $8 \mathrm{~mm}$ were placed in the dilatometer and heated at a rate of $10^{\circ} \mathrm{C} \cdot \mathrm{min}^{-1}$ to various temperatures $(870,900,930$, $960^{\circ} \mathrm{C}$ ). Once the sample was thermally equilibrated after $10 \mathrm{~min}$, a small indenter was released onto the sample and the rate of indentation was used to calculate the temperature $(T)$ dependence of the viscosity ( $\eta_{0}$ in Pa.s; Figure 6). In the narrow temperature span the measurements constrain the viscosity to:

$$
\log _{10}\left(\eta_{0}\right)=\frac{9601}{T-195.7}-3.545
$$

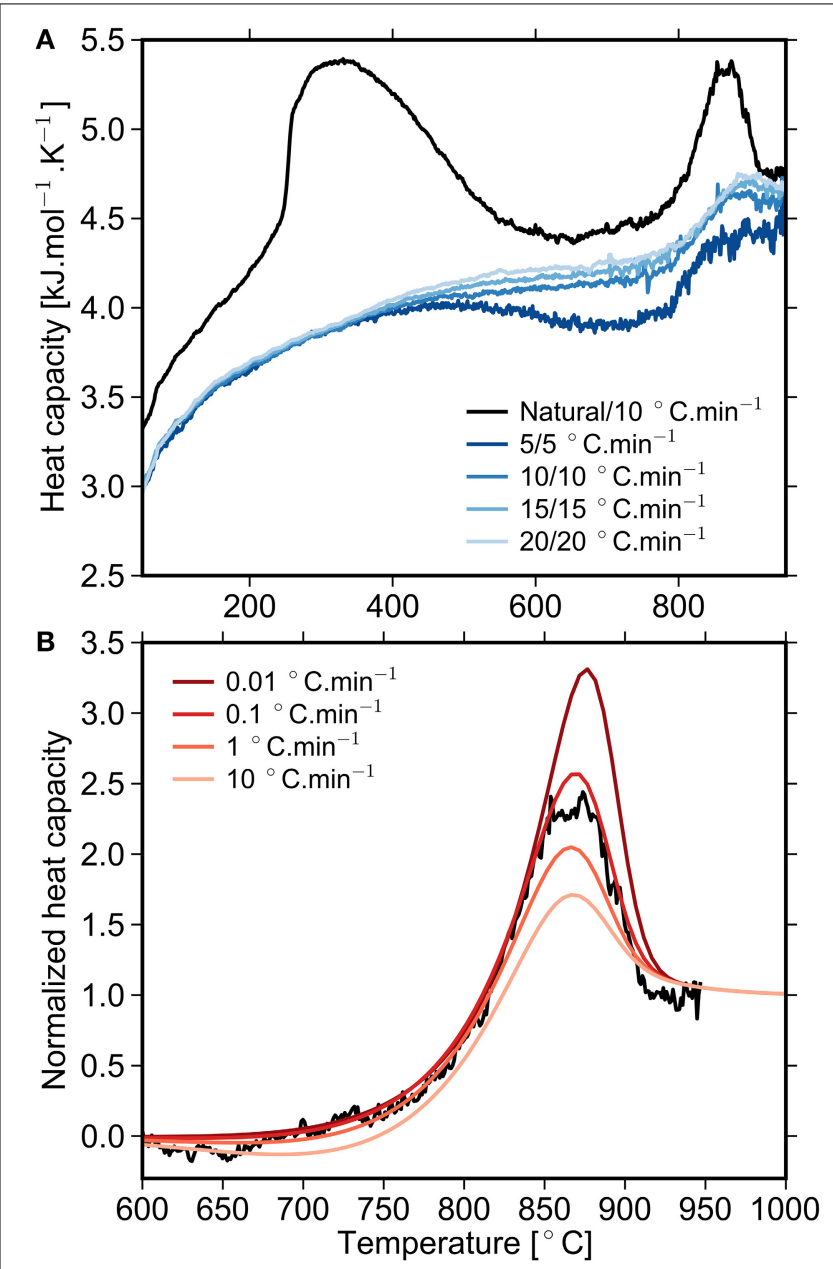

FIGURE 5 | Geospeedometric analysis. (A) Calorimetric measurements during a series of heating/ cooling intervals at different rates. The first heating interval show a calorimetric peak at about $300^{\circ} \mathrm{C}$ which correlates with the dTGA peak (see Figure 3). The second calorimetric peak at $870^{\circ} \mathrm{C}$ is associated with the crossing of the glass transition. (B) Modeled best-fit of the heat capacity of the natural glass, which constrains the depositional cooling rate through $T_{g}$ at $0.1^{\circ} \mathrm{C} \cdot \mathrm{min}^{-1}$.

This temperature dependence of the viscosity is in agreement with the description of a low water content (0.2-0.25 wt.\%) metaluminous rhyolite (Hess and Dingwell, 1996).

The strain rate dependence of the Grey's Landing melt rheology was investigated using a high-temperature $\left(<1300^{\circ} \mathrm{C}\right)$, high-pressure $(1-300 \mathrm{kN})$ uniaxial press equipped with acoustic sensors (see Hess et al., 2007; Lavallée et al., 2008, for detail on the technique). Large cylindrical cores with heights and diameters of 50 and $25 \mathrm{~mm}$, respectively, were prepared and a set of three $2-\mathrm{mm}$ wide holes was drilled along the sample axis to permit the insertion of thermocouples. The sample was placed between the pistons of the press, heated up to given temperatures (900, $920,940^{\circ} \mathrm{C}$ ) and thermally equilibrated for $9 \mathrm{~h}$. Subsequently, a series of loads of $8.0,16.0$, and $24.0 \mathrm{kN}$ (equivalent to stresses of $15.5,31.0$, and $46.5 \mathrm{MPa}$ ) were consecutively applied, the piston displacement was monitored, and the rheology was evaluated. 


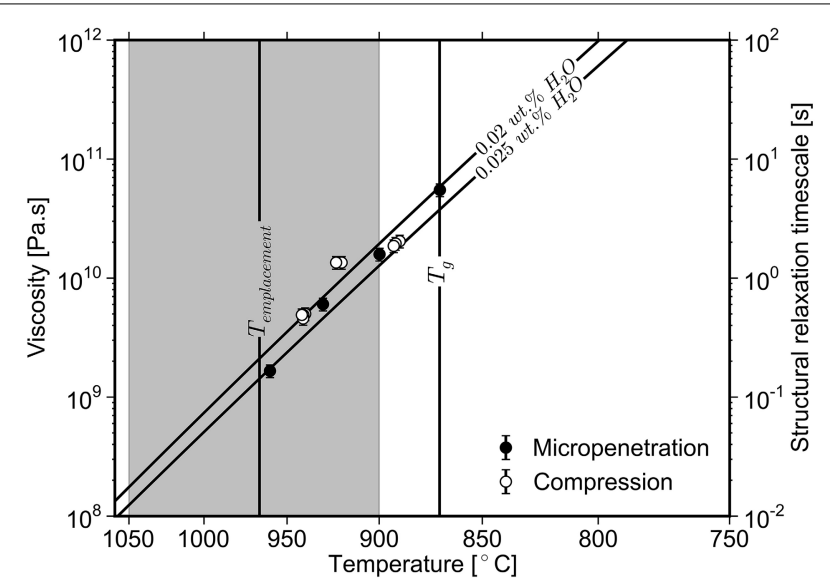

FIGURE 6 | Temperature dependence of viscosity of the vitrophyre within the eruptive temperature window as constrained by geothermometry (gray field) and the glass transition $\left(T_{g}\right)$. The deposition temperature ( $T_{\text {emplacement }}$ ) constrained in Figures 6, 7 is also shown. The solid circles show data obtained by micropenetration and the open circles represent data obtained through the parallel-plate method adapted for a uniaxial press, operating under different applied stresses $(15.5,31.0$, and $46.5 \mathrm{MPa})$ and thus, strain rates. The narrow range of measured viscosities, at a given temperature and despite the range of applied stresses, suggests that the vitrophyre is a Newtonian fluid which does not undergo significant viscous heating within the applied stress conditions.

During the experiments there were no detectable acoustic emissions that would be expected to accompany microcracking of the sample; this implies that all strain was viscously accommodated (e.g., Lavallée et al., 2008). Moreover, we monitored no temperature increase, which would have arisen from any significant viscous heating. Analysis of high-resolution $(20 \mu \mathrm{m})$ neutron tomographic images was used to further investigate the deformation mechanism (Online Supplementary Material). Even in samples with up to $33 \%$ strain, we observed viscous deformation of glass shards and an absence of microcracks. Again, this argues for strain during the deformation experiments to be accommodated by viscous flow.

An equation developed for parallel plate measurements (Gent, 1960) was used to calculate the apparent suspension viscosities $\eta$ :

$$
\eta=\frac{2 \pi F h^{5}}{3 V \frac{\mathrm{d} h}{\mathrm{~d} t}\left(2 \pi h^{3}+V\right)}
$$

where $\mathrm{V}$ is the initial volume of sample $\left(\mathrm{m}^{3}\right), \mathrm{h}$ is the length $(\mathrm{m})$, and $\mathrm{d} h / \mathrm{d} t$ is the rate of length change $\left(\mathrm{m}_{\mathrm{s}} \mathrm{s}^{-1}\right)$. [Note that we use the term apparent viscosity to describe the general rheology of the suspension consisting of liquids, crystals, pores (see Lavallée et al., 2007) without reference to the stress - strain rate description of the rheology]. The calculated viscosities are in reasonably good agreement with the viscosities obtained by dilatometry (Figure 6). We observed no stress (or strain rate) dependence of the apparent viscosity, which could have been associated with an abundance of crystals (Lavallée et al., 2007), with the deformation of pores between glass shards (Quane and Russell, 2005b), viscous heating (Hess et al., 2008) or failure (Lavallée et al., 2008). The observed Newtonian rheology indicates that the basal vitrophyre behaved as coherent viscous liquid typical of lowcrystallinity, low-porosity lavas once the pores collapsed to the observed end-fraction.

\section{TIMESCALE OF THE GREY'S LANDING IGNIMBRITE ERUPTION}

The combination of geothermometry, based on equilibrium crystallization temperature of the mineral assemblage, and geospeedometry, based on glass transition analysis in the welded glass shards, is used to constrain the timescale of eruption and emplacement of the Grey's Landing ignimbrite. Pre-eruptive temperature estimates of $900-1050^{\circ} \mathrm{C}$ (Andrews et al., 2008) and a measured glass transition temperature of $870^{\circ} \mathrm{C}$ allow for a maximum temperature window for cooling of the material during eruption, transport and deposition of $30-180^{\circ} \mathrm{C}$. A complementary rheological study has proposed that viscous energy dissipation during intense shearing may have increased the temperature conditions for rheomorphism by tens of degrees and perhaps up to $250^{\circ} \mathrm{C}$ (Robert et al., 2013). It remains that upon cooling, the basal vitrophyre cooled through the glass transition at a rate of $\sim 0.1^{\circ} \mathrm{C} \cdot \mathrm{min}^{-1}$.

We apply an analytical approach combining a 1D model for conductive heat transfer with a viscoelastic mechanical model to account for progressive changes in heat conductivity in a porous magma undergoing compaction. Our assumptions are (1) that the ignimbrite was deposited instantaneously and (2) that it experienced no deformation during aggradation. Our model is a simplification of nature as it has been constrained that the deposition of pyroclastic density currents results from progressive aggradation (e.g., Branney and Kokelaar, 1992), yet we assume that deposition is extremely rapid and that deposition temperature may be relatively uniform, in order to use current mechanical models. Thus, the starting conditions of the model are homogeneous initial temperature and total porosity. The heat transfer is governed by conservation of energy following the $1 \mathrm{D}$ heat equation:

$$
\frac{\partial T}{\partial t}=\kappa \frac{\partial^{2} T}{\partial z^{2}}
$$

for which $z$ represents the vertical distance $(\mathrm{m})$ perpendicular to the surface of the deposit and $\kappa$ the thermal diffusivity $\left(\mathrm{m}^{2} . \mathrm{s}^{-1}\right)$ of the porous material. The classical definition of the thermal conductivity assumes a pore-free material and, here, we refine this definition to consider the insulation provided by the porosity of the material (e.g., Connor et al., 1997):

$$
\kappa=\frac{k}{\rho C_{p}(1-\phi)+\rho^{f} C_{p}^{f} \phi}
$$

where $k$ is the thermal conductivity $\left(\mathrm{W} \cdot \mathrm{m}^{-1} \cdot \mathrm{K}^{-1}\right), \phi$ the total porosity, $\rho$ and $C p$ the skeletal density $\left(\mathrm{kg} \cdot \mathrm{m}^{-3}\right)$ and specific heat capacity $\left(\mathrm{J} . \mathrm{kg}^{-1} \cdot \mathrm{K}^{-1}\right)$ of the solid respectively, and $\rho^{f}$ and $C_{p}^{f}$ the density and the specific heat capacity of the pore fluid (Table 2). The pore fluid pressure is assumed to be atmospheric, which is 
Table 2 | Initial thermal parameters.

\begin{tabular}{lcccc}
\hline Variable & Value & Melt/Glass & Country rock & Pore fluid \\
\hline $\mathrm{k}_{0}\left(\mathrm{~m}^{2} \cdot \mathrm{s}^{-1}\right)$ & - & 1.59 & 1.59 & 0.025 \\
$\rho\left(\mathrm{kg} \cdot \mathrm{m}^{-3}\right)$ & - & 2900 & 2330 & 1.275 \\
$\mathrm{C}_{\mathrm{p}}\left(\mathrm{J} \cdot \mathrm{kg}^{-1} \cdot \mathrm{K}^{-1}\right)$ & - & 1000 & 1000 & 1007 \\
$\phi_{\mathrm{t}}$ & 0.5 & - & - & - \\
$\lambda$ & 3.6 & - & - & - \\
\hline
\end{tabular}

reasonable considering the lack of confinement to prevent expansion. The thermal conductivity is also a function of the porosity of the material considered. Some empirical models have been proposed to relate the thermal conductivity of a porous rock to its pore-free thermal conductivity $k_{0}$ (Bagdassarov and Dingwell, 1994):

$$
k=k_{0}\left(\frac{1-\phi}{1+\phi}\right)
$$

Analytical solution of Equation (3) for geological systems has most commonly been achieved by assuming self-similarity of solutions (Carslaw and Jaeger, 1947). Assuming homogeneous initial temperature, Carslaw and Jaeger (1959) treat the problem of a cooling magma body in contact with a county rock at $z=0$ and which solidifies at and below its solidus temperature. In our case we use the glass transition temperature in place of the solidus. A derived solution of Equation (3) for the temperature profile in the melt is as follows:

$$
T_{\text {melt }}(z, t)=T_{i}+\frac{T_{g}-T_{i}}{\operatorname{erfc}\left(\lambda \sqrt{\frac{\kappa_{g}}{\kappa_{m}}}\right)} \operatorname{erfc}\left(\frac{z}{2 \sqrt{\kappa_{m} t}}\right)
$$

where $T_{i}$ and $T_{g}$ are the initial and the glass transition temperature (K) of melt respectively, $\kappa_{m}$ and $\kappa_{g}$ the thermal diffusivity of the melt and the glass respectively, and $\lambda$ a non-defined thermal constant. Carslaw and Jaeger (1959) have shown that the temperature profile in the solid portion, here, glass, can be described by the following equation:

$$
\begin{aligned}
T_{\text {glass }}(z, t)= & \frac{T_{g}}{k_{g} \sqrt{\kappa_{c}}+k_{c} \sqrt{\kappa_{g}} \operatorname{erf}(\lambda)} \\
& {\left[k_{g} \sqrt{\kappa_{c}}+k_{c} \sqrt{\kappa_{g}} \operatorname{erf}\left(\frac{z}{2 \sqrt{\kappa_{g} t}}\right)\right] }
\end{aligned}
$$

where $\kappa_{c}$ is the thermal diffusivity of the underlying country rock. The solidification surface occurs following $z_{\text {glass }}(t)=2 \lambda \sqrt{ } \kappa_{m} t$.

This thermal approach is further combined with a mechanistic and kinetic description of the compaction of the deposited ash (Quane and Russell, 2005b, 2006; Quane et al., 2009). The porosity evolution with stress $\sigma$, viscosity of the material at zero porosity $\eta_{0}$ and time $t$ can be derived using the empirical equation (Quane et al., 2009):

$$
\Delta t=\frac{\eta_{0}}{\alpha \sigma\left(1-\phi_{i}\right)}\left[\exp \left(-\frac{\alpha \phi}{1-\phi}\right)-\exp \left(-\frac{\alpha \phi_{i}}{1-\phi_{i}}\right)\right]
$$

where

$$
\phi(t)=\frac{\beta}{\beta-\alpha}
$$

and

$$
\beta=\ln \left(\frac{\alpha \sigma}{\eta_{0}\left(1-\phi_{i}\right)} t+\exp \left(-\frac{\alpha \phi_{i}}{1-\phi_{i}}\right)\right)
$$

Here, $\phi_{i}$ is the initial total porosity and $\alpha$ an empirical constant. Following Quane et al. (2009) we use $\alpha=0.78$ for packing of volcanic ash. The stress distribution across the entire deposit is described by the overburden as $\sigma(z)=\rho(1-\phi) g z$ where $g$ is the gravitational acceleration $\left(\mathrm{m} \cdot \mathrm{s}^{-2}\right)$.

This set of Equations (4-10) provides the tools to iterate a thermo-mechanical model describing the feedbacks between compaction via destruction of porosity, temperature (and thus viscosity) and stress upon deposition. Using a set of constrained glass parameters (Table 2), we simulate the progression of compaction as a function of time and initial temperature (Figure 7). The model results suggest that for the pyroclasts at a stratigraphic height of $z=0.3 \mathrm{~m}$ to reach the measured $\phi=0.075$ at $T=T_{g}$, and a constrained cooling rate of $0.1^{\circ} \mathrm{C} \cdot \mathrm{min}^{-1}$, a little under $1 \mathrm{~h}$ is required. Due to the interplay between cooling and compaction, we can further deduce that $\sim 966^{\circ} \mathrm{C}$ is the idealized deposition temperature $T_{i}$ to meet the measured conditions of porosity, stratigraphic position and cooling rate (Figure 8). This compaction time estimate may be faster if syn-depositional shearing (e.g., Robert et al., 2013) were to have achieved higher stresses than the overburden load considered in our model.

The welding timescale calculated here agrees well with the $12-120$ min proposed by similar rheological modeling by Robert et al. (2013) but is significantly shorter than the $10-15 \mathrm{~h}$ proposed for the Bishop Tuff (Long Valley Caldera, California, USA) by Wilson and Hildreth (1997). In contrast it is orders of magnitude more rapid than the thermo-mechanical constraints on the Bandelier Tuff (Valles Caldera, New-Mexico, USA) estimated at 1-5 days (Quane et al., 2009), the Rattlesnake Tuff estimated at $10 \mathrm{~s}$ of days (Riehle et al., 2010), the Bishop Tuff estimated at 10-100 s of days (Wilson and Hildreth, 1997; Sheridan and Wang, 2005; Riehle et al., 2010), and on a rheomorphic phonolitic fallout deposit (Las Cañadas Caldera, Tenerife, Spain) estimated at 25-54 days (Soriano et al., 2002). The study constrains that welding is not, as previously suggested, decoupled from cooling (e.g., Sheridan and Wang, 2005) but rather is synchronous with cooling. Here we demonstrate that welding (i.e., sintering and formation of eutaxitic textures) reflects the temperature-time window in which the erupted products remain in the liquid state (above the glass transition temperature of the glass fraction of the pyroclasts).

The general agreement between the onset temperature of welding $\left(966^{\circ} \mathrm{C}\right)$ and the geothermometric constraint $\left(900-1050^{\circ} \mathrm{C}\right)$ suggests that little cooling took place during eruption and transport (unless frictional processes contributed in large amounts; e.g., Robert et al., 2013; Lavallée et al., 2014). In this sense, there are strong parallels between large ignimbrites and tuffisites within silicic lava-filled conduits, which exhibit similar dense welding textures (Tuffen et al., 2003). In tuffisites, minimal 


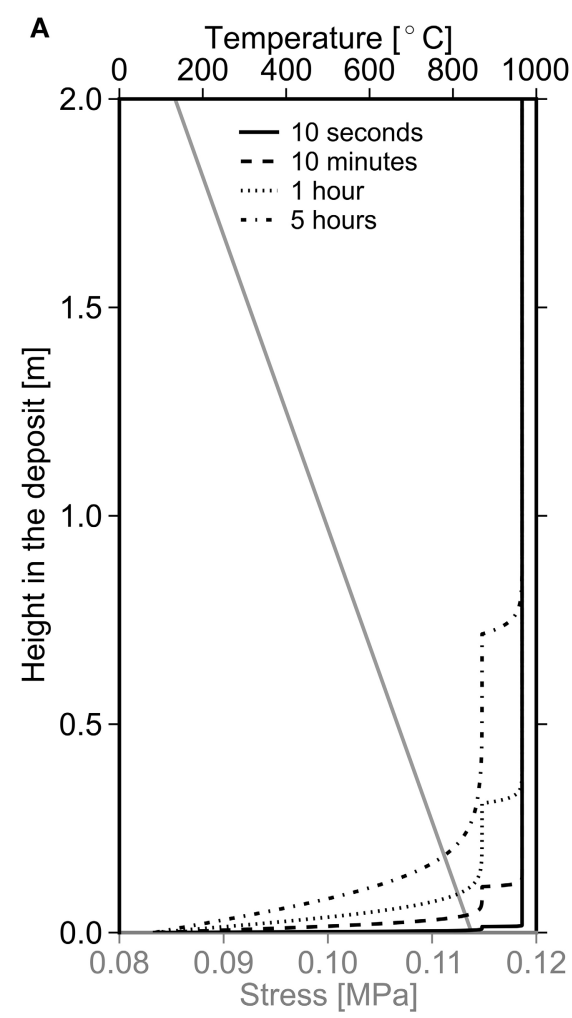

\section{B \\ Porosity} C Cooling rate at $T_{q}\left[{ }^{\circ} \mathrm{C} \cdot \mathrm{min}^{-1}\right]$
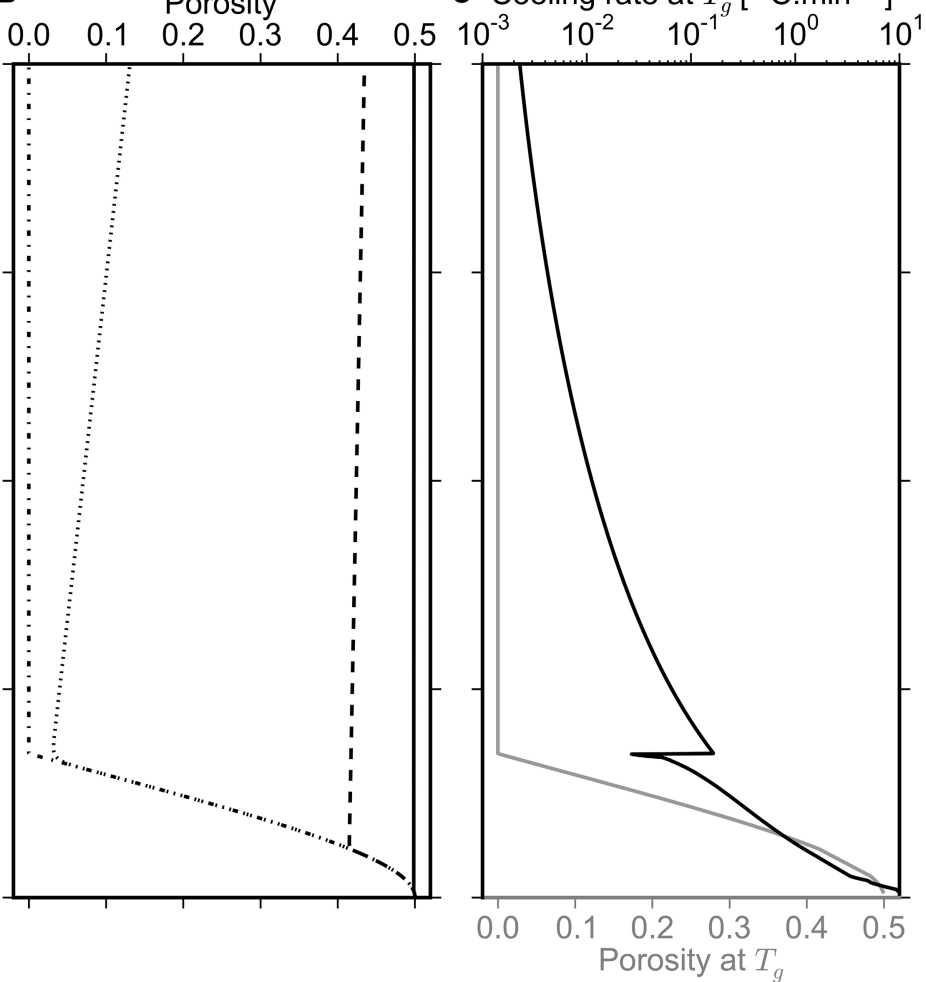

FIGURE 7 | The results of the 1D analytical thermo-mechanical model for the lower half of the deposit at the sampling location. (A) Overburden stress and time-dependent temperature in the deposit after homogeneous initial conditions of $966^{\circ} \mathrm{C}$ and 0.5 porosity. (B) Porosity evolution during viscous compaction and cooling between $10 \mathrm{~s}$ and $5 \mathrm{~h}$. (C) Cooling rate (black line) and porosity (gray line) locked in the glass as the melt crosses $T_{g}$.

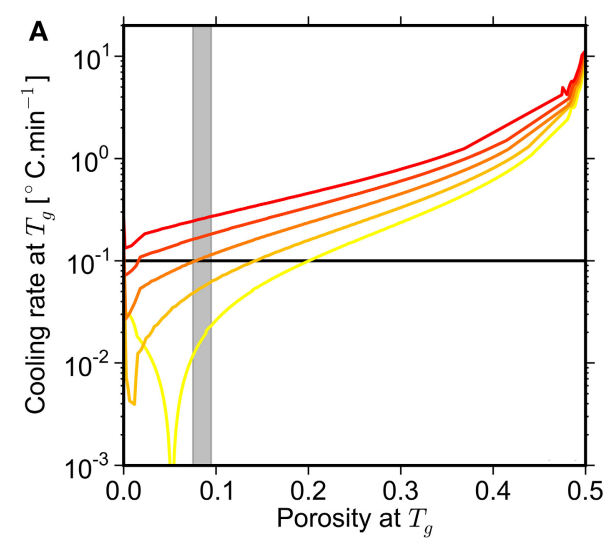

FIGURE 8 | Estimation of the temperature of deposition and the timescale to reach the measured porosity at a stratigraphic height of $30 \mathrm{~cm}$ in the deposit. (A) Intersection of a cooling rate of $0.1^{\circ} \mathrm{C}$. $\mathrm{min}^{-1}$ (black

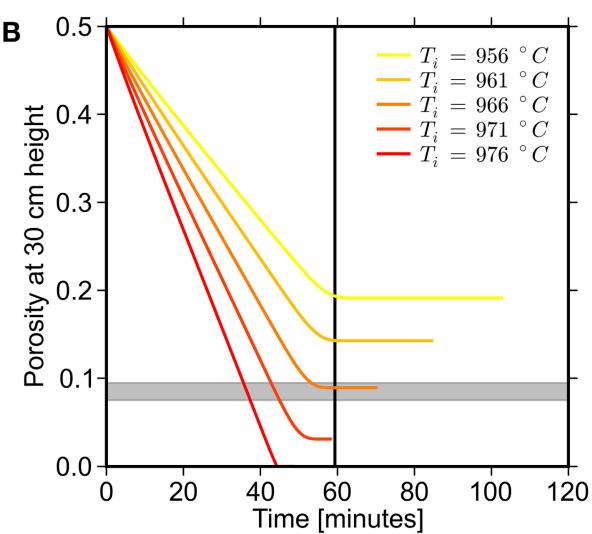

line) and a porosity of 0.075 at a height of $30 \mathrm{~cm}$ (shaded region) constrains an initial deposition temperature of $\sim 966^{\circ} \mathrm{C}$. (B) The time required to produce the porosity observed at a height of $30 \mathrm{~cm}$ whilst cooling $\sim 966^{\circ} \mathrm{C}$ is $55 \mathrm{~min}$.

sub-aqueously (Kokelaar and Koniger, 2000). This must reflect minimal entrainment of surrounding fluids (air or water) during pyroclastic fountaining and flow. It may also reflect a wide source vent (e.g., Legros et al., 2000). Cooling of pyroclasts may therefore be largely prevented until deposition (e.g., Lesti et al., 2011), thus supporting the view that the thermal history of explosive eruptions and emplacement are decoupled. 


\section{CONCLUSION}

The experimental and analytical constraints described above help to unravel the timescales of deposition of large-volume highgrade ignimbrites. The narrow temperature window between the residence in the reservoir and the transition to a glass indicates a high discharge rate, rapid post-fragmentation transport and deposition, and rapid agglutination, welding, and rheomorphism. We estimate the timescale of sintering (welding) and rheomorphism of the basal vitrophyre at a little under $1 \mathrm{~h}$ and further constrain that deposition and onset of sintering occurred when the ash particles approximated $966^{\circ} \mathrm{C}$. Our rheological experiments confirm that, at their original emplacement temperature, the vitrophyres exhibit Newtonian properties at applied stresses up to $46 \mathrm{MPa}$ (corresponding to a $2 \mathrm{~km}$ thick deposit). Thus, the use of the term "lava-like" is physically reasonable for describing the rheological properties of the vitrophyres of high-grade ignimbrites; moreover, it suggests that viscous heating may be minimal for such flow unless applied stresses are significantly higher than those exerted by the overburden. Together, rheological and analytical measurements may serve to constrain the temporal and physico-chemical evolution framework of ignimbrite eruptions and, in the case of the Grey's Landing ignimbrite, support a short timescale of emplacement.

\section{ACKNOWLEDGMENTS}

We thank Ben Ellis and Mike Branney for providing the first sample that spurred this work, and R. Peter Kokelaar for suggestions, which improved the manuscript. Thanks to R. Kendrick for performing the magnetic measurements and A. Lamur for finalizing the related figure. Yan Lavallée acknowledges funding from the European Research Council (ERC) Starting Grant on Strain Localisation in Magmas (SLiM, 306488) as well as the Deutsche Forschungsgemeinschaft (DFG) grants LA2651/1-1 and LA2651/3-1. This project was also partially funded by the European Union's seventh program for research, technological development and demonstration under grant agreement No. 282759 (VUELCO). Donald B. Dingwell acknowledges support from a research professorship from the Bundesexzellenzinitiative (LMUexcellent) and the ERC Advanced Grant on Explosive volcanism in the earth system: experimental insights (EVOKES, 247076). Hugh Tuffen is supported by a Royal Society University Research Fellowship. Graham D. M. Andrews acknowledges support from CSU Bakersfield and NSF award 1137774 . We wish to thank the reviewers Dr. L. Caricchi and Dr. R. Sulpizio for constructive comments.

\section{REFERENCES}

Andrews, G. D. M., and Branney, M. J. (2011). Emplacement and rheomorphic deformation of a large, lava-like rhyolitic ignimbrite: Grey's Landing, southern Idaho. Geol. Soc. Am. Bull. 123, 725-743. doi: 10.1130/B30167.1

Andrews, G. D. M., Branney, M. J., Bonnichsen, B., and McCurry, M. (2008). Rhyolitic ignimbrites in the Rogerson Graben, southern Snake River Plain volcanic province: volcanic stratigraphy, eruption history and basin evolution. Bull. Volcanol. 70, 269-291. doi: 10.1007/s00445-007-0139-0

Bagdassarov, N., and Dingwell, D. (1994). Thermal properties of vesicular rhyolite. J. Volcanol. Geotherm. Res. 60, 179-191. doi: 10.1016/0377-0273(94)90067-1

Branney, M. J., Barry, T. L., and Godchaux, M. (2004). Sheathfolds in rheomorphic ignimbrites. Bull. Volcanol. 66, 485-491. doi: 10.1007/s00445-003-0332-8
Branney, M. J., Bonnichsen, B., Andrews, G. D. M., Ellis, B., Barry, T. L., and McCurry, M. (2008). 'Snake River (SR)-type' volcanism at the Yellowstone hotspot track: distinctive products from unusual, high-temperature silicic super-eruptions. Bull. Volcanol. 70, 293-314. doi: 10.1007/s00445-007-0140-7

Branney, M. J., and Kokelaar, P. (1992). A reappraisal of ignimbrite emplacement - Progressive aggradation and changes from particulate to non-particulate flow during emplacement of high-grade ignimbrite. Bull. Volcanol. 54, 504-520. doi: 10.1007/BF00301396

Brown, D. J., and Bell, B. R. (2013). The emplacement of a large, chemically zoned, rheomorphic, lava-like ignimbrite: the Sgurr of Eigg Pitchstone, NW Scotland. J. Geol. Soc. 170, 753-767. doi: 10.1144/jgs2012-147

Brown, R. J., Buse, B., Sparks, R. S. J., and Field, M. (2008). On the welding of pyroclasts from very low-viscosity magmas: examples from kimberlite volcanoes. J. Geol. 116, 354-374. doi: 10.1086/588832

Carslaw, H. S., and Jaeger, J. C. (1947). Conduction of Heat in Solids. Oxford: Clarendon Press.

Carslaw, H. S., and Jaeger, J. C. (1959). Conduction of Heat in Solids. London: Oxford University Press.

Cathey, H. E., and Nash, B. P. (2004). The cougar point tuff: implications for thermochemical zonation and longevity of high-temperature, large-volume silicic magmas of the miocene Yellowstone hotspot. J. Petrol. 45, 27-58. doi: 10.1093/petrology/egg081

Chapin, C. E., and Lowell, G. R. (1979). Primary and secondary flow structures in ash-flow tuffs of the Gribbles Run paleovalley, central Colorado. Geol. Soc. Am. Special Papers 180, 137-154.

Connor, C. B., Lichtner, P. C., Conway, F. M., Hill, B. E., Ovsyannikov, A. A., Federchenko, I., et al. (1997). Cooling of an igneous dike $20 \mathrm{yr}$ after intrusion. Geology 25, 711-714.

Day, R., Fuller, M., and Schmidt, V. A. (1977). Hysteresis properties of titanomagnetites: grain-size and compositional dependence. Phys. Earth Planet. Inter. 13, 260-267. doi: 10.1016/0031-9201(77)90108-X

Dence, M. R. (1971). Impact melts. J. Geophys. Res. 76, 5552-5565. doi: 10.1029/JB076i023p05552

Denton, J. S., Tuffen, H., and Gilbert, J. S. (2012). Variations in hydration within perlitised rhyolitic lavas-evidence from Torfajokull, Iceland. J. Volcanol. Geotherm. Res. 223, 64-73. doi: 10.1016/j.jvolgeores.2012.02.005

Denton, J. S., Tuffen, H., Gilbert, J. S., and Odling, N. (2009). The hydration and alteration of perlite and rhyolite from Iceland. J. Geol. Soc. Lond. 166, 895-904. doi: 10.1144/0016-76492008-007

Dingwell, D. B., and Webb, S. L. (1990). Relaxation in silicate melts. Eur. J. Mineral. 2, 427-449. doi: 10.1127/ejm/2/4/0427

Dunlop, D. J. (2002). Theory and application of the Day plot (Mrs/Ms versus $\mathrm{Hcr} / \mathrm{Hc}) 1$. Theoretical curves and tests using titanomagnetite data. J. Geophys. Res. 107, 2056. doi: 10.1029/2001JB000486

Ellis, B. S., Branney, M. J., Barry, T. L., Barfod, D., Bindeman, I., Wolff, J. A., et al. (2011). Geochemical correlation of three large-volume ignimbrites from the Yellowstone hotspot track, Idaho, USA. Bull. Volcanol. 74, 261-277. doi: 10.1007/s00445-011-0510-z

Fisher, R. V., Orsi, G., Ort, M., and Heiken, G. (1993). Mobility of a large-volume pyroclastic flow - emplacement of the campanian ignimbrite, Italy. J. Volcanol. Geotherm. Res. 56, 205-220. doi: 10.1016/0377-0273(93)90017-L

Freundt, A., and Schmincke, H. U. (1995). Eruption and emplacement of a basaltic welded ignimbrite during caldera formation on Gran-Canaria. Bull. Volcanol. 56, 640-659. doi: 10.1007/BF00301468

Gent, A. N. (1960). Theory of the parallel plate viscometer. Br. J. Appl. Phys. 11, 85-87. doi: 10.1088/0508-3443/11/2/310

Gottsmann, J., and Dingwell, D. B. (2001a). Cooling dynamics of spatter-fed phonolite obsidian flows on Tenerife, Canary Islands. J. Volcanol. Geotherm. Res. 105, 323-342. doi: 10.1016/S0377-0273(00)00262-6

Gottsmann, J., and Dingwell, D. B. (2001b). The cooling of frontal flow ramps: a calorimetric study on the Rocche Rosse rhyolite flow, Lipari, Aeolian Islands, Italy. Terra Nova 13, 157-164. doi: 10.1046/j.1365-3121.2001.00332.x

Gottsmann, J., Harris, A. J. L., and Dingwell, D. B. (2004). Thermal history of Hawaiian pahoehoe lava crusts at the glass transition: implications for flow rheology and emplacement. Earth Planet. Sci. Lett. 228, 343-353. doi: 10.1016/j.epsl.2004.09.038

Hess, K. U., Cordonnier, B., Lavallée, Y., and Dingwell, D. B. (2007). Highload, high-temperature deformation apparatus for synthetic and natural silicate melts. Rev. Sci. Instrum. 78, 47-50. doi: 10.1016/j.epsl.2008.08.014 
Hess, K. U., Cordonnier, B., Lavallée, Y., and Dingwell, D. B. (2008). Viscous heating in rhyolite: an in situ determination. Earth Planet. Sci. Lett. 275, 121-126. doi: 10.1016/j.epsl.2008.08.014

Hess, K. U., and Dingwell, D. B. (1996). Viscosities of hydrous leucogranitic melts: a non-Arrhenian model. Am. Mineral. 81, 1297-1300.

Kobberger, G., and Schmincke, H. U. (1999). Deposition of rheomorphic ignimbrite D (Mogan Formation), Gran Canaria, Canary Islands, Spain. Bull. Volcanol. 60, 465-485. doi: 10.1007/s004450050246

Kokelaar, P., and Koniger, S. (2000). Marine emplacement of welded ignimbrite: the Ordovician Pitts Head Tuff, North Wales. J. Geol. Soc. 157, 517-536. doi: 10.1144/jgs.157.3.517

Kolzenburg, S., Heap, M. J., Lavallée, Y., Russell, J. K., Meredith, P. G., and Dingwell, D. B. (2012). The strength and permeability of tuffisite-bearing andesite in volcanic conduits. Solid Earth 3, 191-198. doi: 10.5194/se-3-191-2012

Kraut, F., and French, B. M. (1971). Rochechouart meteorite impact structure, France: preliminary geological results. J. Geophys. Res. 76, 5407-5413. doi: 10.1029/JB076i023p05407

Lavallée, Y., Benson, P. M., Heap, M. J., Flaws, A., Hess, K. U., and Dingwell, D. B. (2012). Volcanic conduit failure as a trigger to magma fragmentation. Bull. Volcanol. 74, 11-13. doi: 10.1007/s00445-011-0544-2

Lavallée, Y., Hess, K.-U., Cordonnier, B., and Dingwell, D. B. (2007). NonNewtonian rheological law for highly crystalline dome lavas. Geology 35, 843-846. doi: 10.1130/G23594A.1

Lavallée, Y., Hirose, T., Kendrick, J. E., De Angelis, S., Petrakova, L., Hornby, A., et al. (2014). A frictional law for volcanic ash gouge. Earth Planet. Sci. Lett. 400 177-183. doi: 10.1016/j.epsl.2014.05.023

Lavallée, Y., Meredith, P., Dingwell, D. B., Hess, K. U., Wassermann, J., Cordonnier, B., et al. (2008). Seismogenic lavas and explosive eruption forecasting. Nature 453, 507-510. doi: 10.1038/nature06980

Leeman, W. P., Annen, C., and Dufek, J. (2008). "Snake River Plain - Yellowstone silicic volcanism: implications for magma genesis and magma fluxes," in Dynamics of Crustal Magma Transfer, Storage and Differentiation, eds C. Annen and G. F. Zellmer (Avon: Geological Society Special Publication), 235-259.

Legros, F., Kelfoun, K., and Marti, J. (2000). The influence of conduit geometry on the dynamics of caldera-forming eruptions. Earth Planet. Sci. Lett. 179, 53-61. doi: 10.1016/S0012-821X(00)00109-6

Leonhardt, R. (2006). Analyzing rock magnetic measurements: The RockMag Analyzer 1.0 software. Comput. Geosci. 32, 1420-1431. doi: 10.1016/j.cageo.2006.01.006

Lesti, C., Porreca, M., Giordano, G., Mattei, M., Cas, R. A. F., Wright, H. M. N., et al. (2011). High-temperature emplacement of the Cerro Galan and Toconquis Group ignimbrites (Puna plateau, NW Argentina) determined by TRM analyses. Bull. Volcanol. 73, 1535-1565. doi: 10.1007/s00445-011-0536-2

Manley, C. R. (1992). Extended cooling and viscous-flow of large, hot rhyolite lavas - implications of numerical modeling results. J. Volcanol. Geotherm. Res. 53, 27-46. doi: 10.1016/0377-0273(92)90072-L

Manley, C. R. (1995). How voluminous rhyolite lavas mimic rheomorphic ignimbrites - eruptive style, empalcement conditions, and formation of tuff-like textures. Geology 23, 349-352.

Manley, C. R. (1996). In situ formation of welded tuff-like textures in the carapace of a voluminous silicic lava flow, Owyhee County, SW Idaho. Bull. Volcanol. 57, 672-686. doi: 10.1007/s004450050120

Mellors, R. A., and Sparks, R. S. J. (1991). Spatter-rich pyroclastic flow deposits on Santorini, Greece. Bull. Volcanol. 53, 327-342. doi: 10.1007/BF00280225

Moore, I., and Kokelaar, P. (1998). Tectonically controlled piecemeal caldera collapse: a case study of Glencoe volcano, Scotland. Geol. Soc. Am. Bull. 110, 1448-1466.

Morizet, Y., Nichols, A. R. L., Kohn, S. C., Brooker, R. A., and Dingwell, D. B. (2007). The influence of $\mathrm{H}(2) \mathrm{O}$ and $\mathrm{CO}(2)$ on the glass transition temperature: insights into the effects of volatiles on magma viscosity. Eur. J. Mineral. 19, 657-669. doi: 10.1127/0935-1221/2007/0019-1751

Newman, S., Stolper, E. M., and Epstein, S. (1986). Measurement of water in rhyolitic glasses - Calibration of an infrared spectroscopic technique. Am. Mineral. 71, 1527-1541.

Noguchi, S., Toramaru, A., and Nakada, S. (2008). Groundmass crystallization in dacite dykes taken in Unzen scientific drilling project (USDP-4). J. Volcanol. Geotherm. Res. 175, 71-81. doi: 10.1016/j.jvolgeores.2008.03.037

Quane, S. L., and Russell, J. K. (2005a). Ranking welding intensity in pyroclastic deposits. Bull. Volcanol. 67, 129-143. doi: 10.1007/s00445-004-0367-5
Quane, S. L., and Russell, J. K. (2005b). Welding: insights from hightemperature analogue experiments. J. Volcanol. Geotherm. Res. 142, 67-87. doi: 10.1016/j.jvolgeores.2004.10.014

Quane, S. L., and Russell, J. K. (2006). Bulk and particle strain analysis in hightemperature deformation experiments. J. Volcanol. Geotherm. Res. 154, 63-73. doi: 10.1016/j.jvolgeores.2005.09.025

Quane, S. L., Russell, J. K., and Friedlander, E. A. (2009). Time scales of compaction in volcanic systems. Geology 37, 471-474. doi: 10.1130/G25625A.1

Riehle, J. R., Miller, T. F., and Paquereau-Lebti, P. (2010). Compaction profiles of ash-flow tuffs: modeling versus reality. J. Volcanol. Geotherm. Res. 195, 106-120. doi: 10.1016/j.jvolgeores.2010.06.012

Robert, G., Andrews, G. D. M., Ye, J., and Wittington, A. G. (2013). Rheological controls on the emplacement of extremely high-grade ignimbrites. Geology 41, 1031-1034. doi: 10.1130/G34519.1

Scherer, G. W. (1990). Theories of relaxation. J. Non-Cryst. Solids 123, 75-89. doi: 10.1016/0022-3093(90)90775-H

Schmincke, H. U., and Swanson, D. A. (1967). Laminar viscous flowage structures in ash-flow tuffs from Gran Canaria, Canary Islands. J. Geol. 75, 641-644. doi: $10.1086 / 627292$

Sheridan, M. F., and Wang, Y. (2005). Cooling and welding history of the Bishop Tuff in Adobe Valley and Chidago Canyon, California. JVGR 142, 119-144. doi: 10.1016/j.jvolgeores.2004.10.016

Soriano, C., Zafrilla, S., Marti, J., Bryan, S., Cas, R., and Ablay, G. (2002). Welding and rheomorphism of phonolitic fallout deposits from the Las Canadas caldera, Tenerife, Canary Islands. Geol. Soc. Am. Bull. 114, 883-895. doi: 10.1130/00167606(2002) $114<0883$ :WAROPF > 2.0.CO;2

Sparks, R. S. J. (1976). Grain-size variations in ignimbrites and implications for transport of pyroclastic flows. Sedimentology 23, 147-188. doi: 10.1111/j.13653091.1976.tb00045.x

Sparks, R. S. J., Wilson, L., and Hulme, G. (1978). Theoretical modeling of generation, movement, and emplacement of pyrocasltic flows by column collapse. J. Geophys. Res. 83, 1727-1739. doi: 10.1029/JB083iB04p01727

Stolper, E. (1989). Temperature-dependence of the speciation of water in rhyolitic melts and glasses. Am. Mineral. 74, 1247-1257.

Sulpizio, R., Dellino, P., Doronzo, D. M., and Sarocchi, D. (2014). Pyroclastic density currents: state of the art and perspectives. J. Volcanol. Geotherm. Res. 283, 36-65. doi: 10.1016/j.jvolgeores.2014.06.014

Sumner, J. M., and Branney, M. J. (2002). The emplacement history of a remarkable heterogeneous, chemically zoned, rheomorphic and locally lava-like ignimbrite: 'TL' on Gran Canaria. J. Volcanol. Geotherm. Res. 115, 109-138. doi: 10.1016/S0377-0273(01)00311-0

Suzuki, Y. J., and Koyaguchi, T. (2010). Numerical determination of the efficiency of entrainment in volcanic eruption columns. Geophys. Res. Lett. 37:L05302. doi: 10.1029/2009GL042159

Tauxe, L., Mullender, T. A. T., and Pick, T. (1996). Potbellies, wasp-waists, and superparamagnetism in magnetic hysteresis. J. Geophys. Res. 101, 571-583. doi: 10.1029/95JB03041

Trofimovs, J., Sparks, R. S. J., and Talling, P. J. (2008). Anatomy of a submarine pyroclastic flow and associated turbidity current: July 2003 dome collapse, Soufriere Hills volcano, Montserrat, West Indies. Sedimentology 55, 617-634. doi: 10.1111/j.1365-3091.2007.00914.x

Tuffen, H., and Dingwell, D. B. (2005). Fault textures in volcanic conduits: evidence for seismic trigger mechanisms during silicic eruptions. Bull. Volcanol. 67, 370-387. doi: 10.1007/s00445-004-0383-5

Tuffen, H., Dingwell, D. B., and Pinkerton, H. (2003). Repeated fracture and healing of silicic magma generate flow banding and earthquakes? Geology 31, 1089-1092. doi: 10.1130/G19777.1

Walker, G. P. L. (1983). Ignimbrite types and ignimbrite problems. J. Volcanol. Geotherm. Res. 17, 65-88. doi: 10.1016/0377-0273(83)90062-8

Walker, G. P. L., Wilson, C. J. N., and Froggatt, P. C. (1981). An ignimbrite veneer deposit - The trail-marker of a pyroclastic flow. J. Volcanol. Geotherm. Res. 9, 409-421. doi: 10.1016/0377-0273(81)90047-0

Wilding, M., Webb, S., Dingwell, D., Ablay, G., and Marti, J. (1996). Cooling rate variation in natural volcanic glasses from Tenerife, Canary Islands. Contributions to Mineralogy and Petrol. 125, 151-160. doi: $10.1007 / \mathrm{s} 004100050212$

Wilding, M. C., Webb, S. L., and Dingwell, D. B. (1995). Evaluation of a relaxation geospeedometer for volcanic glasses. Chem. Geol. 125, 137-148. doi: 10.1016/0009-2541(95)00067-V 
Wilson, C. J. N. (1985). The Taupo eruption, New-Zealand.2. The Taupo ignimbrite. Philos. Trans. R. Soc. Lond. A Math. Phys. Eng. Sci. 314, 229-310. doi: 10.1086/515937

Wilson, C. J. N. and Hildreth, W. (1997). The bishop tuff: new insights from eruptive stratigraphy. J. Geol. 105, 407-439.

Wilson, C. J. N., and Walker, G. P. L. (1982). Ignimbrite depositional facies - The anatomy of a pyroclastic flow. J. Geol. Soc. 139, 581-592. doi: 10.1144/gsjgs.139.5.0581

Zhang, Y. X., Xu, Z. J., Zhu, M. F., and Wang, H. Y. (2007). Silicate melt properties and volcanic eruptions. Rev. Geophys. 45:RG4004. doi: 10.1029/2006RG 000216

Conflict of Interest Statement: The authors declare that the research was conducted in the absence of any commercial or financial relationships that could be construed as a potential conflict of interest.
Received: 03 November 2014; paper pending published: 03 December 2014; accepted: 12 January 2015; published online: 04 February 2015.

Citation: Lavallée Y, Wadsworth FB, Vasseur J, Russell JK, Andrews GDM, Hess K-U, von Aulock FW, Kendrick JE, Tuffen H, Biggin AJ and Dingwell DB (2015) Eruption and emplacement timescales of ignimbrite super-eruptions from thermo-kinetics of glass shards. Front. Earth Sci. 3:2. doi: 10.3389/feart.2015.00002

This article was submitted to Volcanology, a section of the journal Frontiers in Earth Science.

Copyright (C) 2015 Lavallée, Wadsworth, Vasseur, Russell, Andrews, Hess, von Aulock, Kendrick, Tuffen, Biggin and Dingwell. This is an open-access article distributed under the terms of the Creative Commons Attribution License (CC BY). The use, distribution or reproduction in other forums is permitted, provided the original author(s) or licensor are credited and that the original publication in this journal is cited, in accordance with accepted academic practice. No use, distribution or reproduction is permitted which does not comply with these terms. 